\title{
Study of the management efficiency of the drinking water supply in arid areas: case of Bechar city (southwest of Algeria)
}

\author{
Mohammed Amin Kendouci $^{1}$ (D) Ali Bendida ${ }^{1,2} \cdot$ Saliha Mebarki ${ }^{1,3} \cdot$ Benali Kharroubi $^{3}$
}

Received: 27 October 2018 / Accepted: 11 October 2019/ Published online: 21 October 2019

(C) The Author(s) 2019

\begin{abstract}
Bechar, a typical Saharan city with an arid climate, receives an average annual rainfall of around $72 \mathrm{~mm}$. Two resources ensure the supply of drinking water to the city of Bechar; the first comes from a catchment field consisting of eight boreholes, and the second comes from the Djorf Torba dam located in the west at about $45 \mathrm{~km}$ where is located the drinking water treatment plant. Water scarcity and water supply disruption have caused residents of Bechar city connected to the water supply system to invest in relatively expensive storage and pumping facilities to meet their domestic needs. The survey was conducted on a sample of $20 \%$ of the population of Bechar city in a period of 4 months. Through the survey, we have reached that $74 \%$ of citizens of Bechar city are not satisfied with the quality and quantity of water and $59 \%$ of respondents are not satisfied with the water pressure and are therefore forced to use the pumps.
\end{abstract}

Keywords Algerian Sahara $\cdot$ Bechar city $\cdot$ Drinking water $\cdot$ Citizen satisfaction $\cdot$ Hours of supply

\section{Introduction}

The sustainable management of water is one of the main axes of sustainable development, as water must meet the needs of current generations and satisfy future generations. The drinking water distributor always has the concern to cover the needs of the consumers; in sufficient quantity and quality, it is also the concern to ensure the good management and the perfection of all the infrastructures contributing to the water supply (Kahlerras et al. 2018). In the regions of emerging countries characterized by an arid climate, the constraints of demographic growth, economic and social transformations are at the origin of an ever-increasing demand for water. In Algeria, the last 20 years have been particularly characterized by a long period of drought due

Mohammed Amin Kendouci aminekendouci@gmail.com

1 Department of Civil Engineering and Hydraulic, Faculty of Technology, University of Tahri Mohammed Bechar, Bechar, Algeria

2 Laboratory of "gestion et traitement des eaux", University of Science and Technology Oran - Mohamed Boudiaf, Oran, Algeria

3 Department of Hydraulic, University of Science and Technology Oran - Mohamed Boudiaf, Oran, Algeria not only to the usual alternation between dry and wet periods but also to the phenomena of climate change. Serious shortages are reported across the country, resulting in deterioration in water quality that poses frequent and complex problems ranging from pollution of waterways to groundwater (Benalia 2012). The drinking water system must be able to satisfy the requirements of consumers in terms of quantity and quality. The water is transported from the source to the distribution point in a chain composed of six main links: resource, capture, production, adduction, storage and distribution. The incorporation or not of the treatment link depends on the quality of the source water (Kettab 2001).

\section{Climate overview of Bechar city}

The climate of Bechar city is monitored by a weather station located in longitude $31^{\circ} 37^{\prime} 00^{\prime \prime} \mathrm{N}$ and in latitude $02^{\circ} 14^{\prime} 00^{\prime \prime}$ $\mathrm{W}$ and with an altitude of $772 \mathrm{~m}$, indexed by 130132 . The station is managed by the National Agency for Hydraulic Resources (Bekhira et al. 2018) (Kendouci et al. 2013). In terms of climate, the city of Bechar is located in the arid zone with a cold winter. The maximum average annual rainfall appears in October with $21 \mathrm{~mm}$; the minimum of $2.3 \mathrm{~mm}$ is in July; the average annual precipitation becomes $72.97 \mathrm{~mm}$, except the period of flood that happened in 

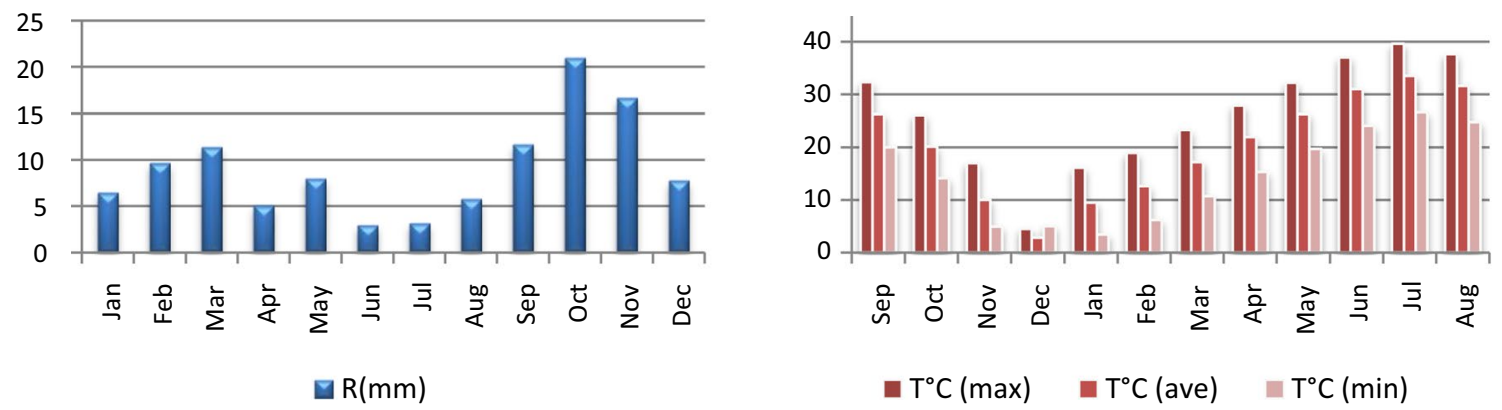

Fig. 1 Rainfall and temperature in Bechar city during the period 1985-2015 (Kendouci 2018)

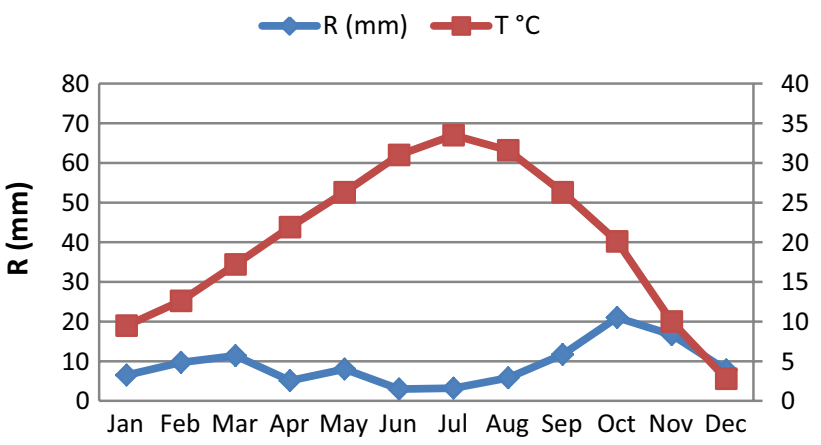

Fig. 2 Ombrothermal diagram of Gaussen of Bechar city

the city of Bechar in October 2008, during which, rainfall exceeded $100 \mathrm{~mm}$ (Kendouci 2018).

The rainy season extends from September to March, with a maximum in October. Minimum temperatures range from 3.4 to $26.6{ }^{\circ} \mathrm{C}$, and maximum temperatures from 16.1 to $39.6^{\circ} \mathrm{C}$ (Fig. 1).

An ombrothermal diagram is a special type of climate chart showing the monthly changes over a year in standardized gradations of temperature and precipitation: A gradation of the precipitation scale corresponds to two gradations of the temperature scale $(P=2 T)$. It was developed by Henri Gaussen and F. Bagnouls to highlight the periods of drought defined by a curve of precipitation (here blue curve) being below the curve of the temperatures (the red curve). According to the Gaussen ombrothermic diagram, the arid period is 12 months in the region (Fig. 2).

The strongest wind blows are in the period from February to September. The evaporation is very intense, especially when it is reinforced by the winds. The maximum average monthly evaporations appear in May with $334 \mathrm{~mm}$ and the minimum of $246 \mathrm{~mm}$ is in December (Kendouci 2018).

Wind plays a vital role in evaporation processes. In fact, the air in the vicinity of the evaporating surface saturates more or less rapidly and can stop the evaporation process. The saturated air is replaced by drier air in the vicinity of the evaporating surface because of the mixtures and movements created by the wind.

\section{Drinking water supply in the city of Bechar}

Two resources ensure the supply of drinking water to the city of Bechar: The first comes from a catchment field consisting of eight boreholes spread over $18 \mathrm{~km}$. The second comes from the Djorf Torba dam located in the West, about $45 \mathrm{~km}$ from where the drinking water treatment plant is located. It was built between 1966 and 1968 (Kabour et al. 2011).

The drinking water supply network of Bechar city extends over $522 \mathrm{~km}$. And the supply water comes to two main sources: the first dam Djorf Torba (surface water) at a rate of $32,000 \mathrm{~m}^{3} / \mathrm{d}$ in 2017 and the second Ouakda aquifer (groundwater) at a flow rate of $8000 \mathrm{~m}^{3} \mathrm{~d}$ with a flow rate of $4320 \mathrm{~m}^{3} / \mathrm{d}$ of Moughel drilling at a total underground flow of 12,320 m³ $/ \mathrm{d}$ in 2017 (Kendouci 2018). For the gravity and pressure adduction, works are used as a treatment station: pumping station of $15,552 \mathrm{~m}^{3} / \mathrm{d}$ and 11 storage and distribution tanks with a total capacity of $26,350 \mathrm{~m}^{3}$. The network of Bechar city covers more than $522 \mathrm{~km}$ of which:

- $60 \%$ of pipes with a diameter of less than $200 \mathrm{~mm}$ (minimum diameter $15 \mathrm{~mm}$ ),

- $35 \%$ of pipes with a diameter greater than or equal to $200 \mathrm{~mm}$. The largest diameter is the DN 800-mm ductile iron (Kendouci 2018). For reasons of practice and not to disturb the daily distribution, we have cut the network taking into account the current configuration of it.

Taking into account the size of the distribution network of the city of Bechar, it is created eight measuring area respecting the pressure stages and the supply of the tanks (Table 1). Each area has been sectorized for a better knowledge of flow distribution (Zekraoui and Brahmi 2017).

In order to optimize the monitoring of drinking water networks and protect customers (houses, all equipment and industrial), municipalities are offered the benefit of 
Table 1 Hours of distribution of each area of the city

\begin{tabular}{ll}
\hline Distribution areas & $\begin{array}{l}\text { Distribution mode } \\
\text { according to the } \\
\text { hours }\end{array}$ \\
\hline Area 1 & $24 \mathrm{~h}$ \\
Area 2 & $8 \mathrm{~h}$ in 2 days \\
Area 3 & $8 \mathrm{~h}$ in 2 days \\
Area 4 & $24 \mathrm{~h}$ \\
Area 5 & $8 \mathrm{~h}$ in 2 days \\
Area 6 & $6 \mathrm{~h}$ in 2 day \\
Area 7 & $6 \mathrm{~h}$ in 2 day \\
Area 8 & $8 \mathrm{~h}$ in 2 days \\
\hline
\end{tabular}

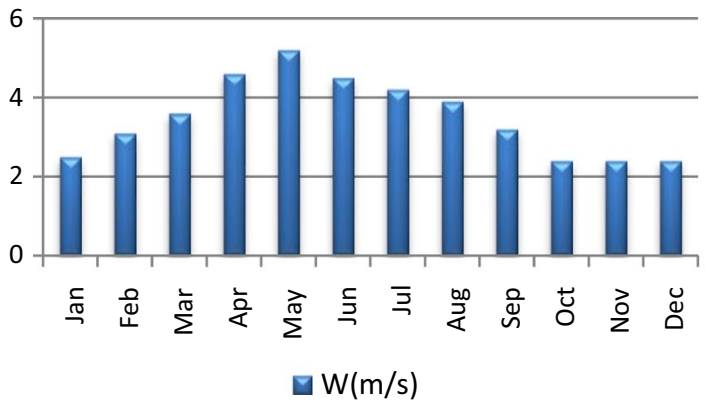

We conducted the survey on a sample of $20 \%$ of the population of Bechar city in the four-month period from February to May 2017 including a survey of $60 \%$ of men and $40 \%$ of women and focused on employers and women home.

\section{Water resources}

Through the results obtained, we find that $55 \%$ of the total citizens of the city declared the water source in Bechar city is the surface water (dam Djorf Torba); $26 \%$ said they do not know the source of the water they consume in their daily lives, and $19 \%$ of those told us that the source of drinking water was groundwater. These percentages correspond to what actually exists because $80 \%$ of the drinking water

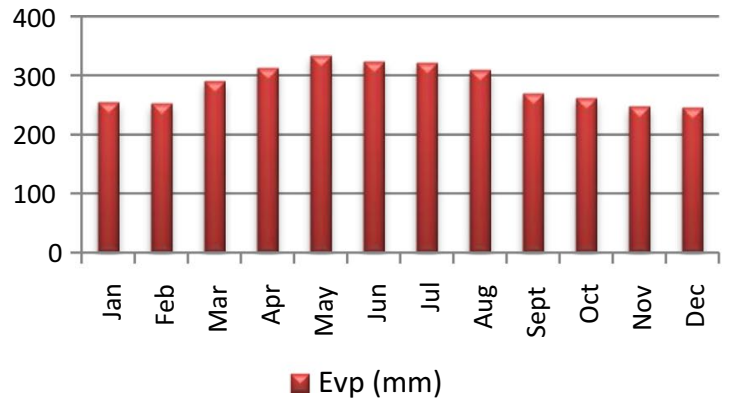

Fig. 3 Wind speeds and average monthly evaporations in Bechar city during the period 1985-2015 (Kendouci 2018)

network monitoring solutions to guarantee optimal water quality and avoid risks contamination, and waste without affecting the water needs of future generations.

\section{Methodology of collection and analysis of data}

To study the problem, we proceeded on the subject of opinion poll based on a series of questions addressed specifically to the inhabitants of Bechar city; the questionnaire prepared contains (Habi and Harrouz 2015):

- General aspects: kind of inhabitants, housing the total number of people living in housing and the type of housing (individual or collective).

- Buy the water and the monthly cost.

- The knowledge of the source of the water consumed in Bechar city and the opinion on the causes of irregular service.

- Hours of supply are sufficient to meet daily needs.

- The presence of water tanks and their volume.

- Satisfaction with water pressure (use of the pump),

- Water bill rate (Habi and Harrouz 2015). supply comes from the dam and $20 \%$ from the groundwater. This explains why the majority of our respondents responded to surface water (Figs. 3, 4, 5, 6).

\section{The water quality of Bechar city}

According to Fig. 7, 74\% of respondents admitted that they are forced to buy water or acquire spring water because they are not satisfied with the quality of the supplied water. These findings correspond to the neighborhoods supplied with groundwater, whose population is estimated at $26 \%$ who are satisfied with the quality of the water they supply.

The chemical composition of water plays an important role in the determination of its quality and the possibility of its use for the supply of drinking water or other uses (Table 2).

The drinking water supply to Bechar city was provided by surface water and groundwater from aquifers (Kendouci et al. 2016). Comparison between the physicochemical content of groundwater and the results of surface water intended for the supply of water to the population makes sure that the two sources offer drinking water. 


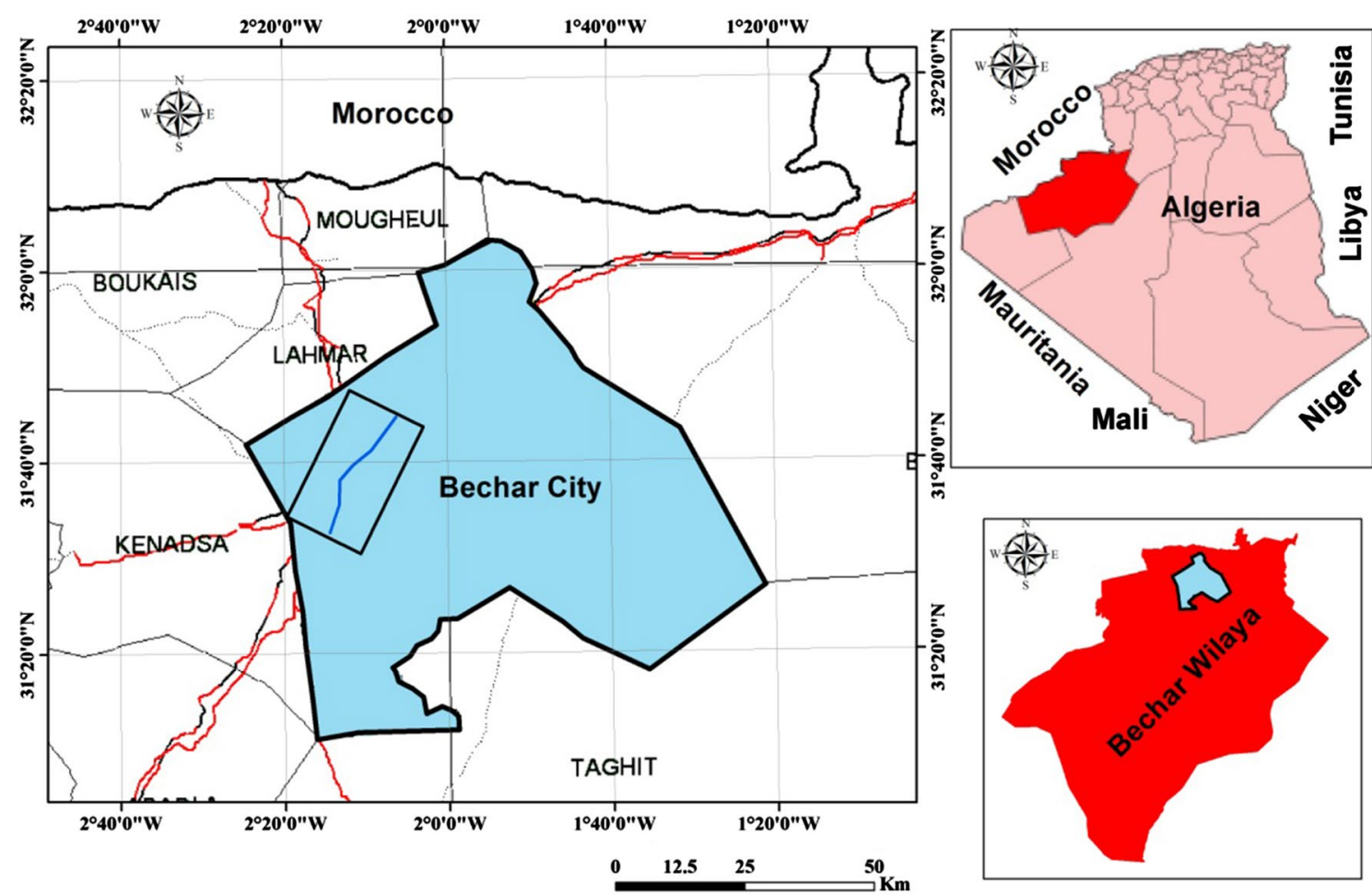

— Limit of Bechar city $\square$ Bechar city $\square$ Bechar Wilaya $\square$ Study area limit

Fig. 4 Study site (Bekhira et al. 2019)

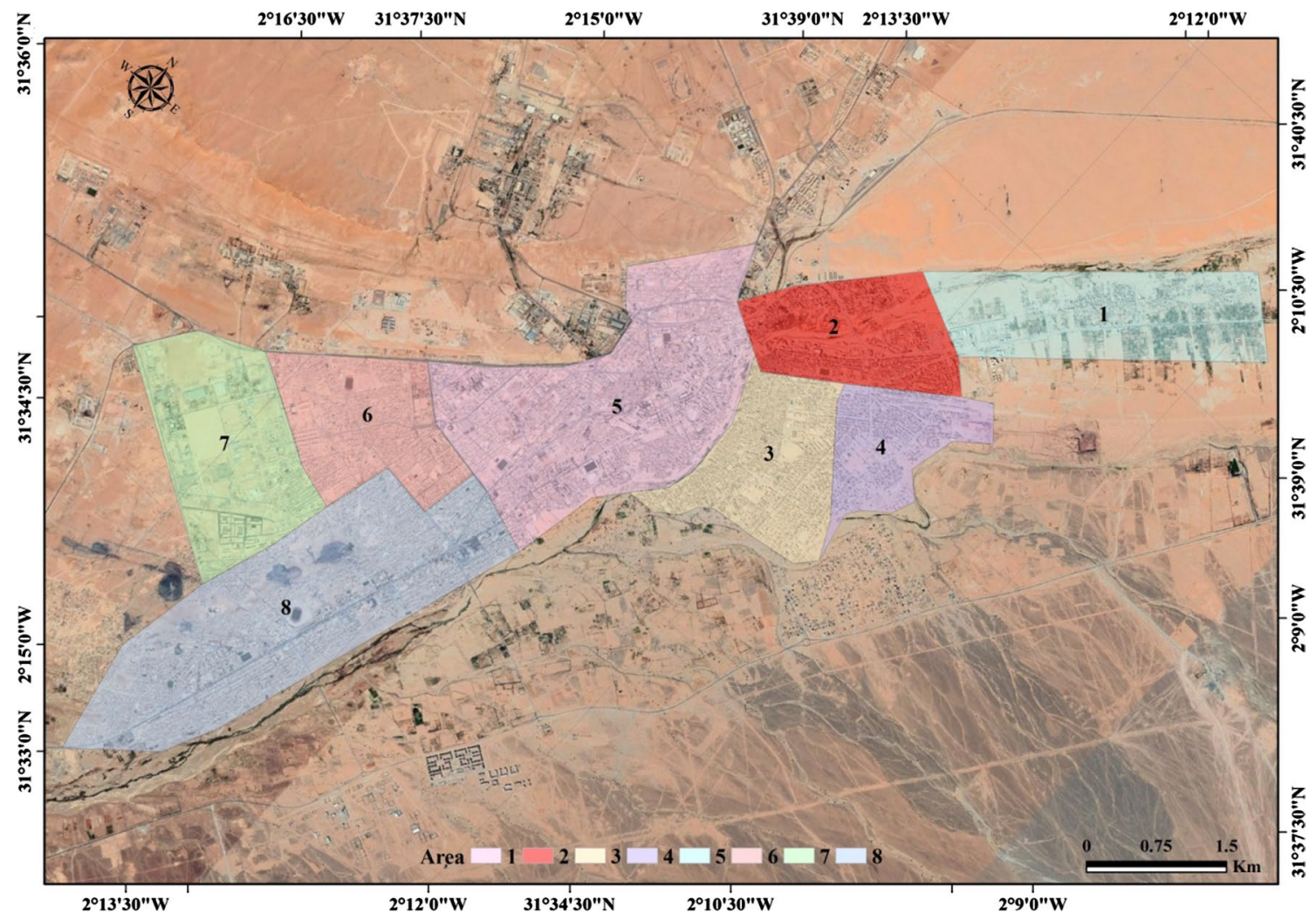

Fig. 5 The distribution areas of Bechar city 

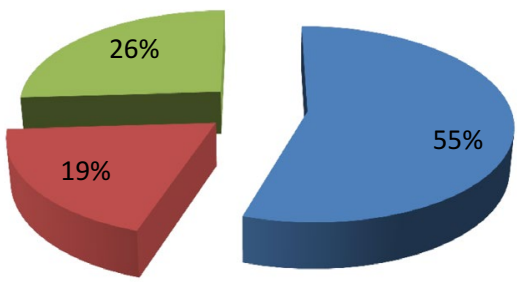

- Surface water

Ground water

I don't know

Fig. 6 Source of water supply of Bechar city

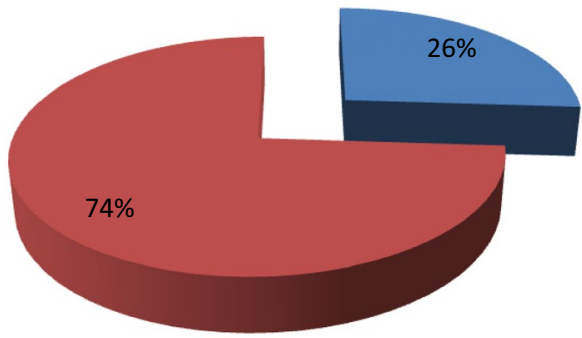

Fig. 7 Satisfaction with quality

Table 2 Physicochemical quality of the surface and groundwater of Bechar city

\begin{tabular}{llll}
\hline Parameters & Unit & Ground water & Surface water \\
\hline Conductivity & $\mu \mathrm{S} / \mathrm{cm}$ & 1020 & 1230 \\
$\mathrm{pH}$ & $\mathrm{Unit} \mathrm{pH}$ & 7.85 & 7.16 \\
Nitrite & $\mathrm{Mg} / 1$ & 0.01 & 0.1 \\
Nitrate & $\mathrm{Mg} / 1$ & 28 & 16 \\
Ammonium & $\mathrm{Mg} / 1$ & 0.02 & 0.05 \\
Chloride & $\mathrm{Mg} / 1$ & 290 & 300 \\
Calcium & $\mathrm{Mg} / 1$ & 58 & 87 \\
Magnesium & $\mathrm{Mg} / 1$ & 57 & 62 \\
Sodium & $\mathrm{Mg} / 1$ & 140 & 75 \\
Potassium & $\mathrm{Mg} / 1$ & 1.9 & 3.5 \\
Sulfate & $\mathrm{Mg} / 1$ & 100 & 210 \\
Phosphorus $^{-1}$ & $\mathrm{Mg} / 1$ & 0.1 & 0.2 \\
$\mathrm{HCO}_{3}^{-}$ & $\mathrm{Mg} / 1$ & 201 & 259 \\
\hline
\end{tabular}

\section{Purchase of bottled water}

Analyzing the results and respondents' responses, we found that the majority of the users said they are not satisfied with the quality and quantity of water supplied, so they have to buy water to meet to their daily needs.

\section{The frequency and the hours of distribution}

The results showed $70 \%$ of respondents who do not know the reason for the irregular distribution of drinking water and only $30 \%$ showed their knowledge to answer the question or they said: scarcity of rain, leakage at the level of network, and some said population growth is offset by the lack of water resources. And also, through the results we find that the majority of respondents said that water is not enough for feeding even after hours of supply to meet daily needs. Distribution hours in the night are from $9 \mathrm{pm}$ to $6 \mathrm{am}$.

\section{The water tank}

According to the results, $97 \%$ of respondents reported having a water tank. The citizens fear water supply breaks for a long time will make them to use the water tank. The results showed that $43 \%$ of respondents reported having a $1-\mathrm{m}^{3}$ water tank, $50 \% 2-\mathrm{m}^{3}$ water tank and $7 \%$ more than $2-\mathrm{m}^{3}$ water tank. It should be noted that respondents prefer to dig underground water tanks (water covers) to avoid hightemperature factor and corrosion.

\section{Satisfaction of the pressure}

The results showed that the majority of respondents said they were not satisfied with the water pressure. This is due to the great distance between neighborhoods and reservoirs. With regard to this topic, the residents of some areas were satisfied with the water pressure, especially after the renewal of the network.

\section{Billing}

In Algeria, the rates set for drinking water vary according to the territorial tariff zone, the category of users and the volume of water withdrawn or supplied. The pricing of public drinking water supply and sanitation services cover all or part of the financial costs related to the operation, maintenance, renewal and development of the corresponding hydraulic infrastructure and installations.

\section{Results and discussion}

In our opinion, there is a lack of communication between consumers and the institution responsible for public water service at the city of Bechar. In addition, Water Awareness Programs are nonexistent; otherwise, how can we explain people who say they do not know their origin of the water they consumed? On the other hand, $70 \%$ of respondents misunderstood the reasons for the irregularity of the water supply; this situation is understandable given the lack of information from water services. It is known that the drinking water supply in the city of Bechar depends mainly on the Djorf Torba demand what is considered insufficient 


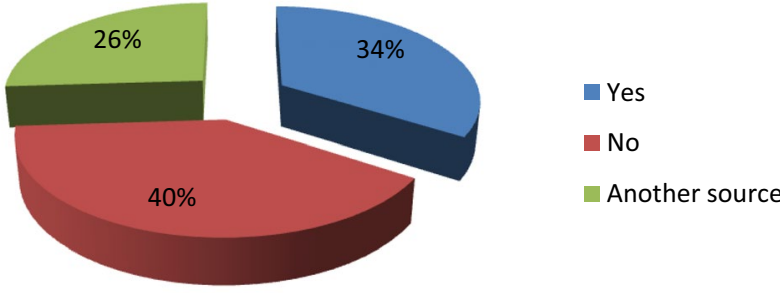

Fig. 8 Purchase of bottled water

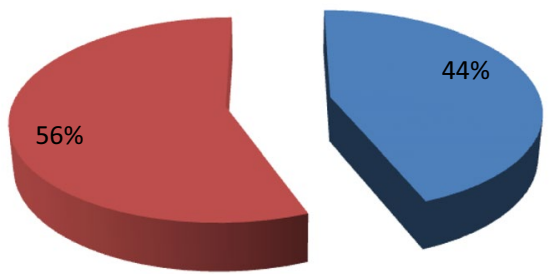

- Satisfied

Not Satisfied

Fig. 9 Satisfaction with supply hours

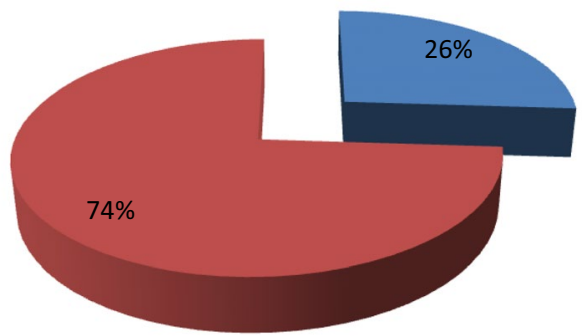

Fig. 10 Satisfaction of the pressure

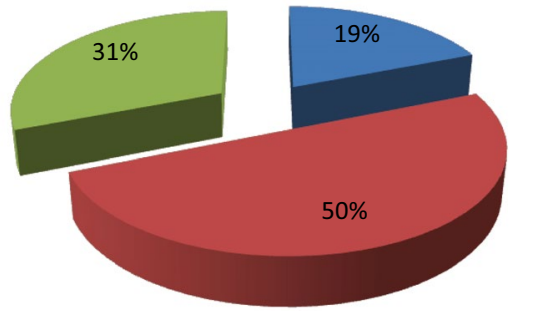

- $<50 €$

$\square 50 €-100 €$

$\square>100 €$

Fig. 11 Water bill rate

given population growth, which forces the state to find other sources of water to fight the deficit (Figs. 8, 9, 10, 11).

With regard to the division of neighborhoods, it depends on the location of the reservoirs, and for the supply of night water, it is related to the process of production and filling of reservoirs. In Oran, the situation is even more critical because of the poor quality of water and the degree of salt it contains. The residents in several districts purchase freshwater (Habi and Harrouz 2015).

The results we obtain are important, especially as they come from the inhabitants of arid area where the supply of drinking water in sufficient quantity and good quality is a prerequisite for the development of the lifestyle of the population.

By comparison, the results of a parallel study in 2013 were given to the city of Tlemcen (North of Algeria) which state that the inhabitants of Tlemcen are satisfied by the quality of the distributed water (92\%) and only about $8 \%$ find that the quality is bad (cloudy water, bad taste). This is a high percentage when compared with surveys conducted in other countries such as that reported in Amman Jordan where only $5 \%$ of inquiries assert that the water of the network is of a good quality, while $65 \%$ find that the quality of the tap water is inferior (Habi and Harrouz 2015). In Tlemcen, as the frequency of water supply is two times per week basis, the survey reveals a discrepancy in terms of volumes consumed and stored by each household. The use of water depends on the individual storage facility and the frequency of the supply (Habi and Harrouz 2015).

\section{Conclusion}

Water is not an unlimited resource; it will be imperative to reverse the trend of a supply adjustment strategy on demand, so that it depends on supply while ensuring the success of other forms of unconventional resource use, such as the use of treated wastewater. Thanks to the survey we have reached, it has been noticed that the society of Bechar city is concerned with the drinking water supply, and the inhabitants need a series of communication and sensitization from the establishment responsible for the public service of water. We can say that the drinking water supply of Bechar city has undergone several changes that are mainly a function of the balance between available resources and needs, and climate and population.

Faced with this assessment, we must make some recommendations that are:

- Deepen the state of knowledge on water resources and develop a fundamental technical document, leading to an integrated management of these resources.

- A detailed population study at the consumption zone level may be necessary in order to understand the evolution of water consumption and better anticipate it.

- Establish a program that includes measures to improve quantitative management.

- Obligation to recycle wastewater and use it for irrigation purposes (watering green areas). 
- Limit construction (urban planning) in perimeter protection zone resource.

- Conduct awareness campaigns for professional structures and for the general public.

Acknowledgements The authors would like to express their gratitude to the MESRS of Algeria, for the support.

Open Access This article is distributed under the terms of the Creative Commons Attribution 4.0 International License (http://creativeco mmons.org/licenses/by/4.0/), which permits unrestricted use, distribution, and reproduction in any medium, provided you give appropriate credit to the original author(s) and the source, provide a link to the Creative Commons license, and indicate if changes were made.

\section{References}

Bekhira A, Habi M, Morsli B (2018) Hydrological modeling of floods in the Wadi Bechar watershed and evaluation of the climate impact in arid zones (southwest of Algeria). Appl Water Sci 8:185

Bekhira A, Habi M, Morsli B (2019) The management of flood risk and development of watercourses in urban areas: case of the town of Bechar. Larhyss J 37:75-92

Benalia O (2012) Modélisation de la demande en eau dans une région aride. Cas de la Wilaya de Djelfa. Revue «Nature \& Technologie» 6:93-105
Habi M, Harrouz O (2015) Domestic water conservation practices in Tlemcen City (Algeria). Appl Water Sci 5:161-169

Kabour, Hani A, Mekkaoui A, Chebbah L (2011) Assessment and management of water resources in an arid area: case of the city of Bechar (South western Algeria). Larhyss 9:7-19

Kahlerras M, Meddi M, Benabdelmalek M et al (2018) Modeling water supply and demand for effective water management allocation in Mazafran basin (north of Algeria). Arab J Geosci 11:547

Kendouci MA (2018) Etude de risque de pollution des eaux souterraines de la ville de Béchar et valorisation du sable en vue de son utilisation en traitement des eaux usées, these de doctorat. USTO-MB, Algérie

Kendouci MA, Bendida A, Khelfaoui R, Kharroubi B (2013) The impact of traditional irrigation (Foggara) and modern (drip, pivot) on the resource non-renewable groundwater in the Algerian Sahara. Energy Procedia 36(2013): 154-162

Kendouci MA, Kharroubi B, Mebarki S, Bendida A (2016) Physicochemical quality of groundwater and pollution risk in arid areas: the case of Algerian Sahara. Arab J Geosci 9:146

Kettab A (2001) Les ressources en eau en Algérie: stratégies, enjeux et vision. Desalination 136:25-33

Zekraoui R, Brahmi M (2017) Etude sociotechnique du réseau d'AEP de la ville de Bechar mémoire de master, Université de Béchar

Publisher's Note Springer Nature remains neutral with regard to jurisdictional claims in published maps and institutional affiliations. 